\title{
Queermuseu: criminalização da produção artística e o papel da arte nas democracias
}

Entrevista com Gaudêncio Fidelis, responsável pela exposição “Queermuseu: cartografias da diferença na arte brasileira", a primeira exposição queer da América Latina, aberta em 2017 em Porto Alegre, no Brasil. Realizada por Simone Amorim Gestora Cultural, PhD em Políticas Públicas (UERJ), Investigadora Associada ao Grupo Cidades e Territórios do DINÂMIA’CET-IUL, Instituto Universitário de Lisboa. E-mail: xsimoneamorimx@gmail.com.

No centro das emblemáticas reflexões da americana Judith Butler (1990), que nos anos de 1990 tornaramse ponto de inflexão da ressignificação do termo queer, está o questionamento da estabilidade da existência dos sujeitos em sobreposição aos seus atos, isto é, anterior ao campo cultural que articulam. À filósofa feminista interessava antes a construção discursiva variável dos sujeitos no e através do outro. A teoria queer é uma reflexão sobre gênero e sexualidade, porém, é sem dúvida uma importante ferramenta epistemológica para pôr em causa a heteronormatividade em si, extrapolando o questionamento ao essencialismo dos binarismos em geral, e é enquanto tal que tem dado importantes contributos políticos para a teoria social.

Esta entrevista a Gaudêncio Fidélis foi realizada no outono de 2019, na cidade do Porto. No centro da conversa estiveram as controvérsias envolvendo a realização da exposição "Queermuseu: cartografias da diferença na arte brasileira", concebida e organizada por este curador brasileiro. O objectivo foi entender, a partir do ponto de vista do seu principal agente, os episódios em torno da primeira exposição queer do Brasil e da América Latina. Nesta conversa, o curador apresenta detalhes dos acontecimentos que desmascararam uma componente conservadora e reacionária da sociedade brasileira, que em pleno século XXI persiste enquanto característica marcante.

Gaudêncio Fidélis é curador e historiador de arte, especializado em arte brasileira moderna e contemporânea e arte das américas. É Mestre em Arte pela New York University (NYU) e Doutor em História da Arte pela State University of New York (SUNY). Foi Diretor do Instituto Estadual de Artes Visuais do Rio Grande do Sul entre 1991 e 1993, fundador e primeiro diretor do Museu de Arte Contemporânea do Rio Grande do Sul (RS) em 1992. Organizou e realizou a curadoria de mais de 50

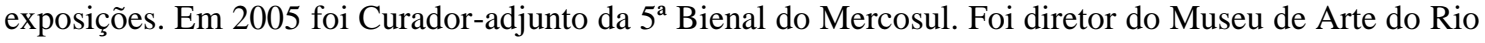
Grande do Sul (MARGS) de 2011 a 2014. Foi Curador-chefe da 10 ${ }^{\mathrm{a}}$ Bienal do Mercosul - Mensagens de uma Nova América, em 2015 e curador da exposição Queermuseu: Cartografias da Diferença na Arte Brasileira, em 2017. Atualmente reside em Nova Iorque e é membro do Conselho do Museu Oscar Niemeyer (Curitiba, Pernambuco).

Palavras-chave: Teoria Queer, Política Cultural, Instituições Culturais, Queermuseu.

\section{A primeira pergunta que eu selecionei é sobre a sua trajetória artística e profissional. Como você caracteriza o seu percurso?}

A minha formação inicial é de Arte, mas quando eu vou para os Estados Unidos da América (EUA) fazer o meu mestrado e posteriormente o doutorado em História da Arte, em Nova Iorque, eu já tinha começado, lá atrás, logo que eu me mudei para Porto Alegre. Para a minha geração as coisas eram muito precárias, por exemplo, pouco se falava em curadoria, quase nem se usava a palavra curadoria ainda, muito pouco. A gente já tinha grandes figuras como o [curador de arte suíço] Harald Szeemann e todas essas coisas, mas era muito incipiente no Brasil, as instituições eram incipientes. Então, eu sou de uma geração que tem que construir o seu próprio espaço de circulação. E eu tinha, olhando em retrospecto, evidentemente, uma 
inclinação muito forte para a reflexão teórica, eu acredito. Daí que meu trabalho artístico naquela época resultou numa produção muito conceitual. Mas quando eu vou para os EUA, bem depois - eu sou de uma geração que teve que trabalhar primeiro para depois poder fazer a sua formação acadêmica superior - eu já tinha acho que 30 anos, e aí ficou muito visível, eu já tinha feito várias coisas: eu já tinha dirigido uma instituição, eu já tinha criado um museu (com 27 anos, eu acho), que foi o Museu de Arte Contemporânea do Rio Grande do Sul, eu já tinha tido uma experiência institucional muito forte para uma pessoa jovem e para aquele momento. Eu decidi que, definitivamente, a minha vocação era organizar exposições, trabalhar em museus e a vida institucional. Mas ironicamente, eu nunca quis seguir a carreira acadêmica, por exemplo. Mas eu queria trabalhar em museus e escrever. Nesse período todo eu estava fazendo várias exposições. O que acontece, e o que eu acho que é relevante para nós e para depois como a gente chega na Queermuseu, é que quando eu comecei a organizar exposições - e hoje eu já organizei mais de 50 - mas de uns 10 anos para cá começou a ficar muito nítido para mim que eu queria fazer exposições que questionassem, testassem, ou tangenciassem de algum modo o cânone da história da arte. No sentido de que o cânone é, a gente já sabe, excludente, mas ele tinha implicações que até então não estavam sendo investigadas ou pensadas através de exposições, e da produção de conhecimento de exposições, e que estão para além daquela ideia de inserir obras não canônicas nas grandes narrativas. Não era esse o objetivo que eu buscava. Eu achava que se você emula demais o cânone e quer inserir as coisas, você se torna cúmplice dele. Mas ao mesmo tempo, e faço essa ressalva, eu não sou uma pessoa contra o cânone da história da arte, por exemplo. Eu acho que o cânone é fundamental para a gente ter um norte, e para a gente poder avançar em determinadas direções, em oposição, paralelo, em contraste a ele de alguma forma. Então, o cânone eu acho que é indispensável. Eu não tenho uma visão iconoclasta de que o cânone deva ser destruído. É muito importante entender isso, porque uma das grandes perguntas que surgiu depois da Queermuseu foi: "de onde você tirou a ideia da Queermuseu?"

\section{Tinha essa pergunta aqui escrita para lhe fazer...}

Essa pergunta está escrita aí eu sei, sempre respondo assim, e eu acho que dá uma certa frustração no início. A Queermuseu não surge de uma ideia, ela surge de um processo. Ela é resultado de um processo que vem se desenvolvendo ao longo dos anos e que começa com essas exposições em que eu elejo um assunto. Eu não acredito em exposições temáticas nem ilustrativas, são duas palavras que eu uso muito, mas elas são banidas da minha práxis curatorial e historiográfica. Eu acredito que exposições têm que ser baseadas num conceito que cria uma plataforma. Eu não uso a palavra tema e também rejeito o caráter ilustrativo. Então, eu comecei a fazer estas exposições, e cito um exemplo bem objetivo: quando fui dirigir o Museu de Arte do Rio Grande do Sul nós desenvolvemos um programa muito extenso de exposições, muito radical, muito avançado. A primeira coisa que fiz foi nomear um curador chefe para o museu e realizei duas exposições (na verdade mais que duas), porque elas tinham relação com a minha formação. E, numa das exposições que eu fiz, comecei a pensar que a história da arte ocidental foi construída exclusivamente com base no olhar, e que os outros sentidos foram relegados a uma hierarquia mais baixa; e um dos que me interessou muito, sobre o qual escrevi um livro inclusive, foi o olfato. Escrevi O cheiro como critério: em direção a uma política olfatória em curadoria. Eu queria muito fazer uma exposição sobre o olfato porque nunca (e estou sendo bem irresponsável com essas frases todas que vou dizer para você), nunca tinha sido feita uma exposição de grande envergadura sobre o olfato no mundo. Pequenas coisas, obviamente, e muito pequenas coisas. Então, eu queria muito fazer essa exposição. Levei quase oito anos tentando e consegui fazer. Queria fazê-la no museu, mas ela dependia muito de patrocínio. Aí eu decidi não fazer porque queria fazer uma exposição de arte brasileira. E aí acabei fazendo na Bienal do Mercosul, que envolvia 22 países e ela se transformou numa das 8 grandes exposições da Bienal, todas concatenadas sobre o olfato e uma exposição de arte da América Latina. Foi fantástico.

\section{Isso foi em que ano?}

Em 2014, em Porto Alegre. Na X Bienal do Mercosul. Mas o que era importante nesse negócio da curadoria olfatória era fazer uma virada epistemológica e parar de pensar, ou pelo menos temporariamente, ou provisoriamente, parar de pensar exclusivamente sob a perspectiva do olho. É como se o olho estivesse aqui e você decidisse olhar para o outro lado e tentar ver as coisas sob uma outra perspectiva. Até porque o olfato, e o cheiro por consequência, tem uma intrusão muito problemática para os espaços museológicos. O cheiro transita, ele é etéreo e é inquantificável. Então ele problematiza uma série de questões. Eu dou 
esse exemplo porque, ao fazer essa exposição, ela já origina um problema, não sob o ponto de vista da polêmica, evidentemente, mas ela origina uma questão, que foi difícil para os especialistas - que aliás são os que tiveram uma grande dificuldade também com a Queermuseu - de entender o modelo de exposição que eu estava utilizando. Por exemplo, as minhas exposições - isso é uma coisa que tenho evitado mas que eu enfatizei categoricamente em relação a Queermuseu - não são exposições essencialistas. Ela não era para representar artistas queer. Ela era uma exposição para discutir o que é o queer e questões queer, mas com a utilização de um universo vasto de obras: que eram obras de artistas queer, que se intitulam queer, obras de artistas não queer, obras que não têm nenhuma relação com o queer, obras formalistas, obras não formalistas, obras que são canônicas, obras não canônicas... e todo esse conjunto de obras reunidas permitiriam construir essa plataforma para discutir a questão. E isso foi muito difícil para as pessoas entenderem. A Queermuseu é um museu provisório, que duraria pelo período de dois meses da exposição. Porque a exposição, além de ter um caráter fortemente museológico, muitas obras emprestadas, $90 \%$ delas emprestadas de coleções de museus, exposições, coleções privadas, a construção dela também é essa coisa de empréstimos, ela de fato dá esse caráter; ela é uma exposição contemporânea e é uma exposição não cronológica. Ela trabalha com justaposições de obras de períodos, estilos, orientações estéticas, vocações, diversas, lado a lado. E a diversidade também trabalha em dois níveis, a diversidade sob o ponto de vista político e das questões identitárias, mas também a diversidade material, porque quando você entra no museu, todas essas questões políticas que tem lá fora - o preconceito, o racismo, a rejeição à diferença, a exclusão, etc. - se refletem nos objetos. Então você tem de ter dentro de uma exposição como essa, eu sempre argumentei muito isso no processo, você tem de ter essa diversidade, que é uma outra diversidade, a diversidade da forma, porque ela tem de refletir também a falta de diversidade lá fora.

\section{Você usa muito duas palavras que são "plataforma" e "cartografia", cartografia meio pelo caráter de processo, será isso?}

Como tem uma história dessas duas palavras no Brasil, na literatura especializada, e tem uma história, por exemplo, na área de curadoria, porque o Ivo Mesquita fez uma exposição muito emblemática chamada "Cartografias", que era uma exposição de artes da América Latina, a qual eu acho que foi até uma exposição muito importante no momento, ela tem um lugar na história, mas eu acho que ela não consegue persistir através da história, com a força que ela poderia ter. Mas cartografia para mim, eu tentei descaracterizar a noção cartográfica tradicional. Talvez uma hora eu venha escrever mais especificamente sobre isso e sobre o subtítulo da exposição porque, ao mesmo tempo que achava que queria desestabilizar a noção da palavra, ela também não era assim uma questão tão fundamental que eu tivesse tempo de discutir. Aliás, o tempo não me foi dado, porque aí a exposição fecha e eu tive que discutir outras coisas. Mas a outra palavra que você mencionou, que é plataforma, eu entendo como um lugar que combina espaço e tempo, é um lugar para a arte, é um lugar construído para a arte. Uma coisa que era muito notável em relação à Queermuseu e que as pessoas falavam, antes da exposição fechar. Porque a exposição foi muito bem recebida, ela fecha abruptamente, porque os protestos, os ataques... desculpe, em relação à exposição durou dois dias e algumas horas e aí ela fecha no domingo, com esses ataques do MBL [grupo ultradireitista brasileiro denominado Movimento Brasil Livre].

\section{E depois teve manifestação, a favor inclusive....}

Sim, ela fecha no domingo, e aí teve uma manifestação extraordinária que reuniu mais de três mil e quinhentas pessoas na frente do Santander Cultural. Aquilo não foi um movimento meu, aliás foi assustador, porque eu vi que estava acontecendo aquilo, mas estava dando milhões de entrevistas, e alguém disse "agora tem uma manifestação"; e quando eu chego lá... meu deus! tinha carro de som, tinha tudo, milhares de pessoas, a comunidade acadêmica, os artistas da exposição, o público do Santander Cultural, o público que está no mailing do Santander Cultural estava lá. Era muito engraçado... Era como quando você vai a uma abertura e está todo mundo dentro, de repente estava todo mundo fora contra o Santander Cultural. Foi muito impressionante aquilo. E evidentemente a comunidade LGBT e LGBTQ e várias outras organizações voltadas para os direitos dos movimentos feministas etc, todos eles é que tinham convocado a manifestação. Mas aí, essa plataforma é um lugar. Por exemplo, as pessoas diziam que essa era uma exposição... olha que engraçado!, até o momento da exposição fechar e os ataques dos setores obscurantistas, a extrema direita e os fundamentalistas se juntarem com um determinado descontentamento de especialistas, não se falava muito sobre o mérito da exposição, vamos dizer assim, sob o ponto de vista negativo. Quando tudo 
isso conflui, há um período ali que, evidentemente não dura muito, porque as pessoas dos setores mais progressistas começaram a observar o seguinte: "bom, nós temos uma opção aqui, nós vamos ter que nos unir em defesa da liberdade de expressão, da democracia e de tudo o que a exposição implica". Então a exposição tem esse mérito. Mas naquele momento as pessoas comentavam que a exposição era um ludgar seguro. Essa é a palavra que eu ouvi muito usarem, para que as pessoas pudessem ver as coisas tranquilamente. Então a plataforma... para mim, exposições são esses lugares construídos para refletir sobre a arte, mas não sob uma visão idealista da arte, mas para ter uma convivência com a arte da maneira que você deseja. Claro que daí a gente não ia imaginar que acontecesse aquela loucura toda.

Tem uma observação que eu queria ver com você, que é o seguinte: você usa muito essa figura do espelho, em que você entra num museu e ele reflete...

Uso! Eu tive dificuldade de usar isso, porque tenho uma crítica à mímesis, mas achei que valia a pena arriscar essa analogia...

A minha questão é a seguinte: tem um filósofo do qual eu me lembrei, pensando sobre essas coisas que eu vi nos seus depoimentos, ele é sul-coreano, estuda o belo na Arte, e fala o seguinte: que um dos problemas da sociedade atual é que ela quer o que abraça ela. Ele está discutindo o belo na arte e faz uma crítica ao artista americano Jeff Khoons e às obras dele, que não fazem nada para pensar a não ser refletir o que já somos e que na acepção dele, a arte não deve abraçar ninguém, a arte deve causar um conflito... então eu queria que você falasse um pouco sobre isso, a arte deve abraçar ou ela deve incomodar?

Na verdade, essa narrativa que acaba sendo construída, tanto a narrativa falsa como a narrativa de que é preciso construir para fazer uma defesa da exposição e de tudo que ela implica, a liberdade de expressão, democracia, liberdade de imprensa, ela é uma exposição que abraça muitas coisas, por exemplo, depois nós começamos a discutir, eu levantei muito essas questões que eu achava que estavam inter-relacionadas, os ataques às religiões de matriz afro no Brasil e assim por diante. Bom, mas aí, ainda acho que a gente vai ter muito tempo, mas nunca houve muito tempo para explicar em mais detalhes determinadas coisas. O que eu queria dizer é que o objeto de arte é imperdoável nesse sentido, ele joga para você, no sentido lacaniano, ele se transforma nesse espelho. Ou seja, é lá que você para na frente dele e reflete os seus sentimentos de exclusão, inclinações de racismos, por exemplo. Porque quando você decide "essa cor é horrível, não consigo suportar" ou "essa obra me causa, não sei o quê" ou "isso não é arte" ou "isso qualquer um faz", essas expressões que a gente conhece tanto; na recusa do objeto, há uma reflexão. Se a pessoa dobrar a esquina você vai ver que não tem como não haver uma equivalência entre a rejeição do objeto de arte e a rejeição ao outro, não tem como, tem equivalência. Então, é nesse sentido. Mas eu não acho que o objeto deva ser condescendente, ao contrário. Tanto que eu chamei a exposição Queermuseu desde o início, o que causou também uma outra confusão, como um choque de imagens. Aí vinham os reacionários e diziam assim: "você queria causar choque nas pessoas". Não, não é isso que eu estou falando. Eu estou falando em conflitos de conceitos e também... eu acredito numa coisa que é: a exposição tem uma força. As pessoas pensam que a causa do problema foi a manipulação, muito bem pensada daquelas cinco obras, que foram transformadas em campo de batalha. Mas tudo que aconteceu em relação a essa exposição só foi possível porque ela era o que era. Ela era uma exposição com uma montagem muito estranha, você não vai notar nada, você vai achar que ela era muito... inclusive, acadêmica porque, por exemplo, eu não uso recursos museográficos, não tem paredes coloridas, a luz é plana, as coisas estão uma ao lado da outra...

\section{Por que você fez essas escolhas?}

Porque, na verdade, a força dela está vindo do confronto entre as coisas. Acredito que as pessoas não haviam percebido o quanto é dramático, complicado e politicamente difícil você colocar uma obra ao lado da outra, que a historiografia e a crítica e a curadoria, jamais fariam, porque isso desestabiliza o lugar, e aí nós voltamos justamente onde me interessa: às questões do cânone artístico. Você desestabiliza o lugar construído da leitura, então, essa é uma exposição, por exemplo, que você tem obras que saíram de museus e que nunca foram lidas como uma exposição que poderia ter inclinações queer. $\mathrm{O}$ artista muitas vezes é queer, ou é um artista LGBT declarado e a obra passou a vida inteira tendo uma leitura estritamente formalista, como se as pessoas tivessem vendo cor e forma, e aí quando ela migra para Queermuseu, ou melhor ainda, quando ela migra para a Queermuseu ao lado de uma outra determinada obra, essa natureza 
intrínseca dela, e talvez a natureza mais verdadeira e legítima, se revela. E aí tudo isso combinado com mais de duzentas obras, com uma engenharia (porque ela tem essa simplicidade, paredes brancas, luz plana, onde não tem sombra, pra você ver as coisas como elas são) ela tem essas justaposições que são não só planejadas lado a lado, ou seja, uma obra que fica ao lado da outra, mas também uma obra que, por exemplo, está à frente e uma outra que está atrás, que se relaciona, ou transversalmente. E tem uma coisa que eu falei, que é até meio complexa: ela tem um caráter que é cinemático, que vem do cinema, de como você observa as coisas e parece que as coisas têm uma outra movimentação, que no final se torna problemático. Porque um dos argumentos que eu vou fazer amanhã e é uma coisa que eu tenho escrito, é sobre animismo e como isso invadiu a nossa relação com os objetos e problematizou o nosso processo cognitivo. Então as pessoas começam a ver os objetos como se eles pudessem, por exemplo, produzir crimes. É isso que acontece ali na exposição e é muito sério, porque as pessoas tratam os objetos como se um quadro fosse sair da parede e cometer pedofilia. Isso tem a ver com uma mudança que eu acho que está acontecendo no nosso processo cognitivo, onde a gente está percebendo as coisas como se elas tivessem vida própria. E isso eu acho que tem uma confluência muito grande ali na exposição. O problema, talvez, é que a exposição, na verdade se antecipa a isso, porque ela está trabalhando com a percepção. Mas aí é uma infeliz casualidade, de que nós estávamos vivendo num mundo que ia deflagrar esse ataque da exposição, justamente baseado nesse delírio cognitivo, que é como eu chamei num texto, em que as pessoas começaram a tratar as coisas na exposição como se elas tivessem vida própria. E um poder de cometer crime, como se a obra de arte como um ser animado pudesse cometer crime. Então isso está no centro dessa questão toda.

Como nasceu essa exposição? Em quanto tempo você a organizou, se você tinha essa dimensão de ser a primeira no Brasil e na América Latina, quais eram os objetivos que você tinha em mente e sobre o que é, efetivamente, a Queermuseu?

Sim. Em algum momento, em 2010, eu comecei. Tem uma exposição que eu fiz antes, no Museu de Arte do Rio Grande do Sul chamada "Cromomuseu". Ela antecede a Queermuseu. Nós cobrimos as 8 grandes galerias do museu, com uma grade cromática extremamente elaborada e complexa de 150 cores especiais e cada uma dessas salas tinha alguma abordagem e algum foco, eram todas obras da coleção do museu e sobre essa grade cromática que estrategicamente eu posicionei determinada obra. Você não tinha mais a obra sobre o espaço branco, ou mesmo que não seja branco, vamos dizer, que seja baseado nos mecanismos da percepção criados para a pintura holandesa, por exemplo, em que você pinta as paredes de verde ou de carmim etc. Mas você não tem mais o fundo neutro sobre o qual a obra possa não ter a interferência do mundo. Então a grade cromática é a cultura, é o objeto jogado no universo da cultura e aí você tem que se ver com um problema. Você tem que lidar com várias escolhas e você destitui a obra temporariamente do lugar canônico dela, do lugar onde ela está isolada do mundo da cultura, para que ela possa realmente ser instituída e observada como uma obra de arte.

\section{Isso cria uma outra obra?}

Não, eu não acho. Eu nunca tive essa intenção. As pessoas têm essa ideia de que as minhas exposições são projetos muito autorais, mas eu não vejo assim. Eu entendo que existam esses projetos autorais, mas na verdade a minha intenção era sempre problematizar o lugar do objeto artístico em relação ao cânone, como eu tinha dito. Mas, era isso que eu queria te dizer. Eu não imaginava que aquela exposição fosse causar tanta polêmica. O público em geral adorou, a exposição era deslumbrante, mas os especialistas têm um pouco de dificuldade, porque eles têm princípios, eles têm determinadas concepções de determinadas obras, de obras que são canonizadas... vamos dizer, um Portinari, ou um Di Cavalcanti. Então é muito difícil essa relação. Quando eu fiz a Queermuseu pensei que o gênero e, especificamente a expressão e identidade de gênero - porque as pessoas podem ter as críticas que quiserem em relação à exposição, mas ela é muito específica na sua terminologia, "expressão e identidade de gênero sob a perspectiva da diferença” - era uma última fronteira para mim, para discutir essa questão do cânone artístico. Mas eu tinha uma coisa clara, em 2010. Havia sido feita uma exposição que chamava "Ars Homoerotica", na Polônia, no Museu Nacional da Polônia, em Varsóvia, que era uma exposição queer, do acervo, uma exposição que foi muito polêmica... enfim, eu conheci o curador, viajei para Los Angeles e conversei com ele, em 2012. Mas era uma exposição que ainda tinha esse viés essencialista, num certo sentido. E também tinha uma outra questão, ela era uma exposição mais histórica, pegava desde a arte grega até à arte contemporânea, que era o acervo do museu e ela se voltava muito para as questões do erotismo e, especialmente do erotismo masculino, a figura 
masculina, etc. que é mais proeminente nos primórdios da história da arte e isso são questões temáticas que eu considero, assim, que para mim já não interessavam mais, mas era uma exposição muito importante porque ela era pioneira. Depois, a Smithsonian, em Washington, fez uma exposição, que também foi considerada uma grande exposição queer sobre o retrato na arte americana, o retrato na pintura, fotografia, etc., se chamava "Hide/Seek", eu comento essas exposições no primeiro texto do catálogo, porque uma das coisas que eu queria fazer era diferenciar. Quando eu falo que essas eram as grandes exposições queer, as primeiras, é porque elas se intitularam queer, tinham o desejo e o objetivo conceitual, artístico e político de serem exposições queer. Então, essa pequena história já tinha mostrado para mim que o que eu queria fazer não era uma exposição essencialista. Eu queria um outro modelo que tinha muito mais relação com os modelos que eu estava fazendo, que era trabalhar em cima de obras, para construir uma plataforma para desenvolver uma determinada questão artística. Então a Queermuseu se transforma nessa exposição, que os especialistas tiveram mais dificuldade, mas o público ficou muito feliz. Claro, a gente tem que desconsiderar os grupos obscurantistas que atacaram a exposição, que esses são uma outra história. Porque as pessoas perguntavam “onde estão os artistas queer?" tinham vários, aí já é um pré-julgamento, porque eu me lembro de uma pergunta que me foi feita numa das primeiras falas que fiz logo que a exposição fechou "por que não tem artistas lésbicas na exposição?". E eu respondi assim: "mas porque você acha que não tem? por que elas não se auto-intitularam lésbicas ou por que elas não pensam a si mesmas como artistas lésbicas? Eu não entendi bem a sua pergunta". Isso foi a primeira parte da minha resposta, claro que o "eu não entendi bem a sua pergunta" foi ironia, mas eu respondi para essa jovem, porque eu vi que a pergunta dela, em tese era bem intencionada. Veja bem, a exposição também não poderia falsear a realidade. $\mathrm{E}$ falsificar a realidade significa o seguinte: primeiro, se você conhece a história, e a história da arte em específico, você vai saber que a presença de mulheres artistas, e mulheres artistas lésbicas, na história da arte é mínima. Isso está na história, está escrito. Ou seja, em primeiro lugar você tem que vislumbrar no horizonte isso. Segundo, isso tem que ser proporcional; você pode também fazer uma exposição e desequilibrar isso. Esse seria o objetivo de uma exposição inclusiva, por exemplo. Mas como eu não estou fazendo uma exposição para representar indivíduos sob o ponto de vista da sua identidade, eu estou fazendo uma exposição para problematizar uma questão, e eu acho que isso ninguém discute, ela realmente fez, eu não posso falsificar a realidade. Então, por exemplo, eu não posso inventar, e nesse caso literalmente seria inventar, 10, 15 artistas lésbicas para ter numa exposição que tem 85 artistas, mas elas estão lá. Isso literalmente seria falsificar uma realidade, sob dois pontos de vista: primeiro, porque não corresponde à realidade, em termos de equivalências; segundo, porque essa exposição não está fazendo isso. E se eu estivesse fazendo isso, talvez pudesse fazer esse desequilíbrio arbitrariamente ou propositadamente. E isso se aplicava a algumas outras situações.

\section{Mas essas são questões que você se colocou na hora?}

Não, não, eu trabalho com a obra.

\section{E como é que você seleciona mais de duzentas obras? Como é o seu processo?}

Por exemplo, quando eu fiz a Bienal do Mercosul, ela tinha quase 650 obras, de 22 países, elas foram exaustivamente, e aí tem uma coisa que eu não conheço nenhum curador que faça, talvez exista algum por aí, mas elas foram metodicamente escolhidas para estar numa determinada posição, lado a lado. E tanto é assim, que se você pegar o catálogo da Bienal, que tem 1008 páginas, ele tem um texto de 1 milhão e meio de palavras, que é o texto principal, ele comenta cada uma das quase 650 obras da exposição, e porque elas estão lado a lado, e porque esta se relaciona com esta e porque esta se relaciona com aquela outra. E o texto da Queermuseu, do primeiro catálogo, um dos textos, também faz isso. Ele discute obra por obra e o porquê de ela estar lá, quais são as questões básicas daquela obra, porque ela está ao lado da outra, o que ela provoca. Isto está lá, eu fiz o meu trabalho, as pessoas podem discordar. Bom, essa engenharia, esse quebracabeça é muito complexo porque envolve também diplomacia, você tem que negociar essas obras.

\section{Em quanto tempo mais ou menos?}

Acho que 1 ano e meio. Mas eu quase morri.

Eu achei que era muito mais, porque são tantas obras... 
Mas eu estava me dedicando só a isso. E aí eu discuti com várias pessoas. Por exemplo quando eu fui negociar as obras da Lygia Clark, eu discuti com o Presidente [da Associação Cultural "O Mundo de Lygia Clark"], o Álvaro que é o filho dela, eu discuti porque eu queria tal e tal obra. Porque aí tem outro detalhe: eu não quero qualquer obra da Lygia Clark, quero esta obra específica. Então quando eu fui discutir com os artistas, vários artistas, cuja obra não tem nenhuma relação com o queer - ao contrário, rejeitam a noção - eu fui dizer para eles que queria a obra deles numa exposição; que eu queria esta obra e não aquela... é sempre uma coisa muito difícil, que eu fiz e faço. E eu só tive um não - e isso está tudo documentado nos arquivos da exposição, que são monstruosos - que foi uma obra, um vídeo do Hélio Oiticica, mas eu não achei que a recusa fosse pelo conteúdo da exposição, foi por questões de restrição.

\section{Tinha outras obras do Hélio Oiticica?}

Não, na exposição não. Tinha Lygia Clark, tinha Portinari, tinha Pedro Américo, tinha Guignard... eu fui convencer colecionadores que tinham essas obras a emprestar e isso me causou um tumulto porque as pessoas [falavam], mas Portinari é queer? Não, nunca foi! A sua obra? Não, também não! Mas tem uma pintura dele na exposição, um retrato que ele fez de um médico, que era do movimento integralista, e que é inacreditável a pintura, se você vir a foto e vir o que eu escrevi... e ela foi uma pintura que foi rejeitada. Foi um retrato recusado porque ele tinha justamente essas características afeminadas. E ele quebrou o realismo, ele quebrou o contrato entre retratado e a idealização do retrato. Ele retratou como era o retratado e aí a pintura passa muitos anos na obscuridade, ela vai para os porões. Depois, hoje ela está numa coleção de uma pinacoteca municipal em Porto Alegre, uma pintura de corpo inteiro, na escala do corpo. Então, é uma exposição muito complexa sobre esse ponto de vista, e ela se torna muito mais complexa quando sofre esse processo dramático de censura e se transforma na maior - aí eu vou usar a palavra de novo - na maior plataforma de defesa da liberdade de expressão, da democracia, dos direitos e de tudo o que diz respeito à inclusão e que a exposição pode abarcar. Porque, por exemplo, a exposição tinha questões relativas à religião... uma das obras que foi utilizada para criar essa narrativa falsa e que foi acusada de vilipêndio religioso é uma obra que trata da transubstanciação. Tem também "Cruzando Jesus Cristo com a deusa Shiva", que é uma obra sobre sincretismo religioso. Eu falei sobre essas obras na CPI [Comissão Parlamentar de Inquérito, realizada pelo Senado federal], que eu acho que é o lugar mais público, gravado em vídeo em que eu falo e faço um tour sobre aquelas cinco obras para a indignação do Senador Magno Malta. Enfim, essa exposição tem essa complexidade já inerente.

Você mencionou que trabalhou pra conseguir as obras, conversou com os artistas, falou sobre o que era a exposição. Eu imagino que você tenha escrito um projeto para Lei de Incentivo, tenha buscado o patrocínio com o Santander Cultural, etc. Teve uma série de etapas, todos estavam sabendo o que era a Queermuseu. A partir de que momento se dá essa ruptura? Foi só quando abriu a exposição ao público e ela vai para a opinião pública?

Não! Ela foi a exposição mais celebrada do Santander Cultural e teve mais de 3500 pessoas na abertura, o maior público que o Santander Cultural teve desde a sua inauguração em uma abertura de exposição. Ela foi celebrada durante aqueles 32 dias que ficou aberta e teve um recorde de público, mais de 30 mil visitantes naquele período. O que acontece é muito mais simples do que parece, e depois, claro, muito mais complexo do que parece. O MBL [Movimento Brasil Livre] realiza esse ataque à exposição.

\section{Eles foram os grandes responsáveis?}

Eles foram os únicos e exclusivos responsáveis. Eles agora estão dando entrevistas dizendo que nem conhecem a Queermuseu... é mais ou menos isso que o Kim Kataguiri e o Renan estão dizendo, porque isso deu-lhes um prejuízo político muito grande e esse prejuízo continua aumentando, principalmente agora que eles querem ingressar em uma outra fase, que eles esgotaram a primeira fase. Eu vou dizer uma coisa que eu disse várias vezes e que está em muitas entrevistas: agora eu acho que eles fizeram uma guinada para um outro lugar, que não é mais benéfico, ao contrário, mas eu considerava o MBL um prestador de serviços, ou seja, eles prestavam serviços para os fundamentalistas, para setores obscurantistas da sociedade, para os evangélicos e assim por diante.

Mas eu acho que até mais seriamente para alguns setores empresariais, setores que inflam esses grupos... 
Sim, sim. Então, eles encontraram na Queermuseu, num momento propício, todos os ingredientes para catapultá-los numa plataforma nacional em torno da questão dos costumes e do universo simbólico, que era a última fronteira de ataque que eles tinham que fazer. Eles não tinham feito isso ainda. Eles tinham, por exemplo, iniciado lá em 2013 - eu sempre cito esse exemplo - porque quando em 2013 aquele pessoal foi para a rua e no qual o MBL estava muito envolvido, a plataforma de defesa deles era segurança pública. Quem é que vai questionar que segurança pública é uma defesa legítima? Mas o que se estava construindo ali? Uma noção de que você precisa de segurança pública, porque num futuro breve, quando houvesse um acirramento - como logo acontece no primeiro experimento, isso eu estou dizendo da minha cabeça, mas para mim é muito claro que é a intervenção militar no Rio de Janeiro - as pessoas já estariam preparadas. Elas estariam achando ótimo, porque legitima um discurso que foi construído e que não vai então causar um estranhamento. Então eles haviam feito vários ingressos, na área econômica, nessa questão da segurança pública, na corrupção e assim por diante, porque isso está nos playbooks do fascismo e eu considero eles um grupo de inclinações fortemente fascistas - eu disse isso em todas as entrevistas que dei, que se utilizavam exaustivamente de táticas de milícias, e eu acho que eu fui a primeira pessoa que usei isso. Os parlamentares e as lideranças políticas demoraram seis meses para utilizar a palavra fascismo, que eu estava usando desde o primeiro dia, e fundamentalismo até hoje eles têm dificuldade. Mas a Queermuseu oferece essa plataforma extraordinária e eles fazem isso de uma maneira muito eficiente, escolhem essas cinco obras, muito bem escolhidas para atingir determinados públicos, e inclusive, por exemplo, a mais notória pra mim é quando eles fazem essa acusação de um detalhe de uma pintura da Adriana Varejão, que não é a pintura, acusando-a de pedofilia para atingir justamente os setores da sociedade envolvidos com a defesa dos animais, a defesa do meio ambiente etc. Então eles escolhem cada parcela, cada obra servia a uma parcela.

Até porque quando eles questionam que as obras estavam ferindo a religião, eles não pegam as obras de religião de matriz africana...

Não. Aliás, ontem eu até citei esse exemplo, na própria pintura da Adriana Varejão (“Cenas do Interior”) tem uma cena... Essa pintura pra mim faz referência às mazelas do colonialismo, da colonização brasileira etc., e aí tem uma cena de dois homens brancos numa relação sexual com um homem negro, e o MBL não pega aquela cena, por exemplo, porque o MBL recusa sistematicamente a existência da escravidão, ou do racismo. Para eles não existe racismo, então eles jamais pegariam aquela cena que, evidentemente, em tese seria mais polêmica se isolada do contexto. Então ela aparece de vez em quando, se algum desavisado do MBL, que não é do núcleo central, pega aquela imagem e aí ela circula. O próprio [senador] Magno Malta vai à tribuna um dia e faz um apelo à comunidade negra que se revolte contra aquilo, o que aliás absolutamente nada acontece, porque ficou muito claro pra mim que a comunidade de afrodescendentes entendeu que aquilo era uma grande manipulação. E a exposição tinha questões de denúncia de racismo, que aliás também nunca foram tocadas por eles, pelo MBL e os seus subsequentes seguidores, e não teve nada. Pelo contrário, posteriormente, quando a gente vai para o Rio de Janeiro, temos uma enorme ligação com grupos envolvidos com militância de periferia, com a comunidade negra, com as religiões afro, etc., e é tudo incrível. Esses detalhes - sobre os quais a gente poderia falar por horas - precisam ser entendidos para que as pessoas percebam a engenharia por trás disso. Mas aí depois, claro! O MBL deflagra esse processo e é seguido pelos fundamentalistas religiosos, setores ultrarreacionários da sociedade, fanáticos e, especialmente, lideranças políticas que resolvem subtrair disso benefício de caráter eleitoreiro, porque nós estávamos indo em direção a uma eleição e é um projeto obscuro que depois se instala com clareza.

Você falou um pouco sobre esse momento de ruptura. Eu queria também ouvir a tua avaliação sobre as instituições. Claro, central é o Santander Cultural, o papel da Prefeitura do Rio, o governo do estado do Rio de Janeiro e a escola de artes visuais do Parque Lage, o próprio Ministério da Cultura que aprovou o projeto. Mas você teve algum tipo de restrição ou sanção posterior por não ter executado na Lei Rouanet [lei de incentivo à cultura]? $\mathrm{E}$, por último, essa coisa do crowdfunding $\mathrm{e}$ da organização das pessoas em oposição ao movimento organizado do MBL.

Aí tem várias etapas, primeiro o Santander Cultural... Num primeiro momento eu não daria tanta importância à atitude do Santander Cultural agindo como uma instituição. Foi mais uma reação de indivíduos na respectiva direção, que respondem a interesses escusos e à sua vontade própria. O que eu entendo ali é que... claro, eu não estou dizendo com isso que essas pessoas não são a instituição..., mas 
não foi uma decisão de política institucional. É um erro de decisão que acaba sendo assumido pela instituição. O Superintendente, na minha opinião, deveria ser sumariamente demitido, embora seja funcionário do banco. Ele não foi porque o Santander Cultural entende que o dano público seria ainda maior. Mas eles não medem as consequências. Do que eu acompanhei, eu vou contar isso no meu livro em mais detalhes... porque são fatos muito precisos, então se eu fizer afirmações muito categóricas, fica complicado. Mas eu entendo que quando São Paulo, no meio daquela crise com os ataques do MBL pergunta para Porto Alegre “como está a situação aí? devemos fechar?” Eu tenho certeza de que ele disse que sim, tenho indícios que isso aconteceu... Eu estava em casa e só fiquei sabendo depois, pelo telefone. O Carlos Trevi só me ligou uma hora e meia depois e me pergunta se eu não gostaria de falar com ele. Eu disse: não há nada para falar, nós não temos nada para falar! Desliguei o telefone e nunca mais falei com ele. $\mathrm{Na}$ verdade, ele ainda me ligou um dia depois dizendo que eu não deveria dar entrevistas e aí, eu nem vou dizer o que eu disse a ele... Eu creio que numa atitude intempestiva ele disse "eu sou a favor de fechar" e aí o Santander Cultural fecha. Porque eles têm que o consultar, porque ele é o Superintendente local, e então eles cometem um erro inominável. Mas também porque eles não preveem que por trás daquela exposição, para a infelicidade deles, tinha um curador que iria sair numa campanha. Eu decidi em 5 segundos quando li aquela nota, o comunicado oficial do Facebook. Aí eu leio e chego no meio, quando eu li a frase "a exposição foi cancelada", eu pensei: não, eu não li direito, vou ler de novo!, eu li. E aí quando eu realmente me dei conta, a sensação que tive foi inimaginável. É uma coisa que passou pelo meu corpo todo e não sei descrever, eu nunca tinha tido e espero que nunca vá ter na minha vida. Mas eu me recuperei em 5 minutos, até porque o telefone começou a tocar e nunca mais parou. Naquelas 72 horas eu fiquei dando entrevista sem parar, sem dormir inclusive. Para todos os organismos internacionais, o New York Times já me ligou no início do dia seguinte, quando já tinha começado a extrapolar na imprensa nacional. A primeira entrevista foi O Globo, que me ligou. Eu estou contado esses detalhes porque acho importante entender como essa coisa acontece, ela é orgânica. Eu nunca procurei a imprensa. E quando passou aqueles segundos, em que me dei conta do que aconteceu, eu peguei uma folha de papel - eu tinha feito a Bienal do Mercosul, então tinha muito contacto com a imprensa, da América Latina como um todo, inclusive. Eu não atendi o telefone num primeiro momento, e anotei em algumas frases a narrativa que eu ia colocar em curso, o que era importante: eles não me consultaram, foi uma decisão unilateral, isso tudo foi claro pra mim, é um processo de censura declarado. Aí eu atendi o primeiro telefonema, que foi O Globo... teve órgão de imprensa que esperou seis horas para falar comigo. Mas isso foi importante, porque esta era a minha ponte com a sociedade. Eu decidi que ia contra-atacar esclarecendo a sociedade, e de uma maneira exaustiva, que foi o que fiz durante um ano.

\section{Você disse que na sua avaliação o controle não é uma política do Santander Cultural, mas você não acha que está inserido no que essas empresas estão fazendo com a estratégia de marketing por meio do patrocínio às artes e à cultura, a deturpação das leis de incentivo?...}

Não. Eu acho que é importante clarificar duas coisas. Não é num primeiro momento, mas logo se transforma, se materializa, ou seja, porque você tem que entender o lado pragmático... se eles pensassem no prejuízo, porque depois eles tiveram que investir milhões em marketing para tentar contrabalançar o estrago, que não parou nunca mais. Ou seja, se eles olhassem pragmaticamente, eles não fariam isso. Mas, sob o ponto de vista institucional, essa atitude intempestiva vai se encontrar com a natureza conservadora do Santander Cultural. A gente precisa esclarecer isso bem, porque isso que é adotado pelo Santander Cultural... agora os bancos têm manuais de censura prévia, eles entregam para o curador dizendo: você pode fazer isso, não pode fazer aquilo, etc. O primeiro que criou isso foi o Itaú, já faz tempo. Que é o grande patrocinador, lembrando que o Itaú nunca tinha censurado uma exposição. O maior patrocinador da América Latina em Arte nunca tinha censurado uma exposição. E quando então me diziam "isso é a lógica dos bancos", eu fiz questão de dizer “não é!". Veja bem, você pode fazer todas as críticas aos bancos, mas esse episódio tem outros fatores que precisam ser considerados. Tem que entender primeiro o episódio. Senão pode correr o risco de criar uma teoria, que logo em seguida vai desabar, porque lá no início ela tem uma pequena falha. Mas, de fato, o Santander Cultural se revela uma instituição ultraconservadora. É bom lembrar que o Santander Cultural no Brasil é independente do Santander Cultural Espanha, juridicamente. Então essa decisão foi tomada aqui. E até onde eu sei, de uma fonte segura, causou uma profunda irritação, porque o estrago foi internacional. É a mesma marca. E o Santander Cultural Espanha tem, inclusive, uma coleção de arte muito bonita. A outra coisa é que esses indivíduos que estavam no comando, nas 
presidências, são indivíduos que além de não gostarem de arte, obviamente, não têm nenhum escrúpulo e nenhuma consideração por uma instituição que já tinha, na época, 17 anos de existência. Ou seja, como é que o Santander Cultural constrói o seu prestígio? Exclusivamente com as leis de incentivo fiscal? Não. É com o empréstimo de centenas e dezenas de obras que eles usaram na exposição, graciosamente emprestadas. Inclusive, da Queermuseu. O prestígio do público que vai lá. O prestígio dos curadores, dos artistas. Isso é um capital que eles acumularam durante 17 anos e que eles apertaram um botão e em 5 minutos implodiram. E a outra coisa que eu acho que é preciso dizer em relação ao Santander Cultural é que ele não consegue entender o que significa uma instituição. Ou seja, eu descaracterizei o Santander Cultural como uma instituição logo no segundo dia, porque instituição não pode cometer um crime contra a arte e contra a cultura. Ela está neste momento destituída do seu caráter institucional, ela não institucionaliza mais nada. E eu digo, todas as vezes que me perguntam, o Santander Cultural é uma instituição censora e os artistas que, ingenuamente ou não, participam ainda (porque muita gente se recusa) das atividades do Santander Cultural, eles estão do outro lado da classe artística. Porque com o histórico que o Santander Cultural construiu, que eu acho que uma grande parcela da comunidade artística reconhece, não é mais possível que ele exista como instituição.

\section{Fale um pouco dos outros, da prefeitura, do Parque Lage...}

Bom, eu recebo logo em seguida um telefonema surpreendente, porque eu não tinha contato com o Evandro Salles, do Museu de Arte do Rio (MAR), dizendo assim: "Gaudêncio, nós vamos trazer a exposição para cá, nós queremos", eu fiquei... assim... Porque naquele momento eu nem estava pensando em reabrir a exposição, eu estava pensando em construir uma espécie de resistência. Mas fui agindo meio intuitivamente, até porque eu não tinha alternativa. E aí eu peguei um avião, fui ao Rio conversar com eles e começou todo o planejamento.

\section{Enquanto isso as obras ficam lá no Santander Cultural?}

Então, esse é um detalhe importante. O Santander Cultural promoveu um sequestro das obras. No momento em que cancela a exposição ele deveria devolver as obras aos seus emprestadores imediatamente. Acionar a produção e fazer isso, ele retém as obras por mais de um mês, sob o protesto de todo mundo. Como se fosse numa cena de crime, tudo cercado com fitas.

\section{Você tinha acesso?}

Não, não. Mas eu também me recusei a dialogar com o Santander Cultural, porque não havia diálogo com eles. Eu tinha que enfrentá-los publicamente. Mas eles teriam que tomar as providências para fazer a devolução, porque eles romperam com o Acordo de Empréstimo. O Acordo de Empréstimo é um acordo que obedece a parâmetros internacionais, às vezes você tem taxas de manutenção etc., mas você faz um empréstimo gracioso. E assim que as instituições funcionam em toda parte do mundo, e o Santander Cultural recebe essas obras de empréstimo e retém por mais de um mês. Ele só começa o processo de retorno, simbolicamente, no último dia em que a exposição fecharia. Sob toda uma batalha judicial que estava acontecendo, inclusive o fato de que a exposição estava sendo, enquanto estava lá, difamada, os artistas atacados e o Santander Cultural retendo essas obras, mandando a mensagem para a sociedade de que essas obras eram objeto de crime, que elas eram desabonadoras. Aliás, o que está numa das frases da nota infeliz que eles lançam, porque eles condenam as obras, moralmente. Bom, aí quando o Museu de Arte do Rio resolve levar a exposição, começa o planejamento. Nós chegamos a planejar o lançamento e rapidamente a gente sentiu que começou a haver um probleminha, que partiu não se sabe bem de onde... a gente imagina mas enfim, mas ela vai parar no gabinete do Prefeito. E a longa história curta é que eu estava em Minas [Gerais] fazendo uma palestra e estava falando com a Clarissa Diniz sobre a reunião que teria no outro dia no MAR, e soube que a Secretária [Municipal de Cultura] iria e que haveria uma intervenção. Eles estavam sentindo que haveria uma intervenção, mas eles me disseram isto: "nós vamos segurar a exposição". Às sete da manhã, antes de ir para a palestra, eu falo com o presidente do MAR ao telefone e digo para ele: "Gradim, é o seguinte, eu acho que vocês devem fazer a defesa da exposição por questão de princípio institucional, mas se a situação ficar como ela está parecendo que vai ficar, vocês recuem" inclusive, porque eles estavam sinalizando que pediriam demissão em massa, porque era insustentável que uma instituição fosse censurada e assim por diante - "vocês devem recuar, porque na minha opinião, a Queermuseu terá um outro lugar”. Eu juro que disse com essas palavras e não conheço curador que faria 
isso: a Queermuseu terá um outro lugar e o MAR não existirá se houver uma intervenção da Prefeitura, nesses termos que eles estão colocando que eu não posso nem dizer para ti porque vou dizer no meu livro. Então foi isso que eles fizeram. Mas eu acho que a coragem do MAR fica muito definida. Teve muita gente que criticou o MAR sobre isso, mas eu não porque acompanhei todo o processo e sei como foi, porque eles lançaram uma nota - apesar de tudo, apesar das ameaças do prefeito - dizendo "nós somos a favor que a exposição fosse feita aqui”. E eles foram em frente ainda, altíssimo risco. As ameaças que ele [Prefeito Marcelo Crivella] fez foram assim: "amanhã, todos os evangélicos estarão aqui e tchau para o museu", foi assim. Bom, quando sai essa notícia, alguém me diz assim: "Você viu que o Diretor do Parque Lage disse que vai levar a exposição para o Rio? Eu disse, quem? Porque eu não conhecia o Fábio [Szwarcwald], eu só disse "Ah, que ótimo" e fui fazer outra palestra e foi isso que aconteceu. Ele não falou comigo, enfim, mas aí nesse meio tempo eu sou chamado pelo [coletivo artístico] 342, a Paula [Lavigne] fala comigo, pede que eu vá ao Rio. Eu estava numa outra palestra em São Paulo (naquela missão... era uma palestra por dia...), eu disse “não vai dar tempo!”. Eu acabei chegando lá era dez e meia da noite. Já tinha um estúdio preparado, 150 pessoas estavam lá, inclusive o Fábio, e foi quando eu conversei com ele. E foi uma coisa assim, vamos conversar amanhã, e foi isso. Aí nós gravamos aquele vídeo em defesa da liberdade de expressão, contra a censura, que atingiu uma visualização absurda, mais de cinco milhões e quinhentos e tantos mil compartilhamentos. Mas a campanha já estava em curso e ela cresce, cresce, cresce...

\section{E não teve nenhuma restrição do Governo do Estado do Rio de Janeiro?}

Não. Ao contrário. No outro dia o Fábio convida o Secretário [Estadual de Cultura, André Lazaroni], e ele está na reunião, e a reunião foi ótima. Tudo correu bem, mas houve depois algumas interferências no final, porque quando o [Secretário] Leandro [Monteiro] assume a Secretaria, o Leandro tem muitas dificuldades com a exposição, e num determinado momento ele demite o Fábio nas vésperas da exposição, o que ocupou a imprensa nacional. Eu liguei para o ex-secretário e para o Leandro e disse que se ele não fosse restituído imediatamente, a exposição não ia acontecer com a outra diretora, que eu nem conhecia. Porque você não pode pegar uma exposição daquela envergadura, com aqueles empréstimos, com aquela complexidade, com seguro, com toda a engenharia, com a questão política que tem por trás e dali a quinze dias abrir, com uma pessoa que desconhece a exposição. E eles restituíram o Fábio [Szwarcwald] naquela noite. Essa é a verdadeira história. Ela mais ou menos circula pela imprensa. Houve também um movimento forte do 342 contra a demissão dele, que colaborou imensamente. Mas eu também dei esse telefonema, porque cabia a mim como curador tomar uma decisão independente da questão política. Então aí são teorias conspiracionais, você poderia me perguntar: houve alguma intervenção do [Prefeito Marcelo] Crivella? Porque foi um desafio ao [Prefeito Marcelo] Crivella fazer a exposição no Rio. Quando o Crivella faz aquele vídeo acusando a exposição de pedofilia, eu acionei ele judicialmente (porque não tem nada que eu não tenha feito), porque achei que tinha que fazer uma defesa, e não era uma defesa do mérito da exposição, eu tenho até feito essa ressalva muito contundentemente. Eu não defendi o mérito da exposição enquanto ela estava fechada. Eu defendi antes, obviamente como curador, nas dezenas de entrevistas que dei antes de a exposição fechar. Mas quando a exposição fechou a discussão para mim era outra. A discussão era sobre liberdade de expressão, sobre democracia, sobre esse crime contra a arte e contra a cultura brasileiras, sobre a criminalização da arte e assim por diante. Em defesa dessas questões eu utilizei todos os recursos dentro da lei que eu achava que deveriam ser utilizados, com base na Constituição. Judicializar, eu achei que era importante, o Ministério Público (MP), todas as ações políticas que nós fizemos. E aí nós organizamos também, durante o processo pré-abertura da Queermuseu vários eventos no Rio, para dar um substrato para a exposição e dar mais visibilidade, e evidentemente o crowdfunding, que foi muito preparado. E ele é muito bem-sucedido porque tem uma das causas mais legítimas e populares que você pode imaginar, que é reabrir uma exposição pelas mãos da sociedade brasileira e aliás, muitas pessoas perguntaram isso: "vocês fizeram isso porque não tinham patrocínio?" Eu acho que a gente teria patrocínio, porque a mídia que a exposição tem é absurda. Mas a decisão que a gente tomou e que veio de mim foi assim: nós agora vamos reabrir essa exposição pelas mãos da sociedade brasileira. É esta a mensagem política que nós vamos mandar. E aí saiu a ideia do crowdfunding. Só que os crowdfundings, com exceção daquele "Jornada para a Democracia" da [ex-presidente] Dilma [Rousseff], nunca tinham atingido um patamar acima de 600mil [reais] e nós precisávamos de 800mil, no mínimo. Quem ia fazer o crowdfunding do MAR seria a 'Catarse', e aí acabou que o pessoal da 'Benfeitoria' se aliou e não nos cobraram taxas, eles queriam se envolver no processo, e aliás, estrategicamente foram muito bem, eles bateram o recorde. 
Eles achavam que era impossível ultrapassar a faixa dos 350 - e eu me lembro que tive uma conversa com o Fábio e disse que tinha que ser 700 para começar, mas não vai dar, as pessoas vão levar um susto e também não vai chegar o dinheiro, então vamos colocar 690 - mas aquilo foi considerado uma loucura. A gente planejou muito bem e quando apertamos o botão do crowdfunding ele estava preparado para ser bemsucedido. Quando eu comecei a fazer aquelas palestras eu já estava dizendo para as pessoas: "nós vamos reabrir a exposição, será através de um crowdfunding e nós precisamos da colaboração de vocês". Em cada lugar que eu ia fazia isso. Então, eu realmente me imbuí dessa tarefa e decidi que ela seria bem-sucedida. E acreditava que se ela fosse, isso seria um símbolo para um momento futuro que eu já estava antecipando. Eu disse: "se preparem, vai bater na porta de todo mundo, as universidades serão atacadas daqui a semanas". E aí eu vi que as pessoas olharam, eu tinha alguma mediunidade? Não. Por ter sido diretor do MARGS [Museu de Arte do Rio Grande do Sul], depois a Bienal, eu já estava sentindo que a Queermuseu era apenas o começo.

George Yúdice refere que "a performatividade hoje é aplicada ao social, inaugura uma nova epistemologia do engajamento social". Eu gostaria que você falasse um pouco sobre como vê a possibilidade dessa não heteronormatividade, a propósito do queer, se isso tem entrada no espaço da cidade neoliberal de hoje. Acho que a exposição também deu elementos para se pensar as cidades, as pessoas, as instituições e a arte. A arte pode alguma coisa, dentro desse estado de coisas que a gente vive? O exemplo é do Brasil, mas eu acho que isso extrapola também para os reacionarismos e conservadorismos atuais na Europa... Como você pensa a estética queer no espaço da cidade hoje?

Isso é muito importante. Escrevi um texto - deve ter sido em 2014, foi publicado em um dos livros teóricos da Bienal - que era sobre o que chamei de curadoria não heteronormativa, aí já dá aquele estremecimento. Curadoria não heteronormativa não é uma ideia de que você só vai fazer exposições com artistas e obras com inclinação LGBT, não! É de que você vai, de novo, inverter o pensamento, fazer uma inversão reflexiva e talvez uma mudança epistemológica, porque a heteronormatividade é pervasiva. Assim como a questão do olfato, para mim também era isso. Aí eu escrevi isso, mas na época, eu escrevi meio assim, eu tenho esse hábito de escrever coisas que acho que são mais especulativas e que eu sei que daqui a pouco vou elaborar mais, é um processo. Várias vezes durante a Queermuseu eu disse que as pessoas tinham que pensar de uma maneira mais queer, e também fui criticado pelo uso dessa palavra. Inclusive, por me manter atrelado à utilização da palavra em inglês. Porque ela tem um histórico também e eu sou meio ortodoxo no sentido da minha relação com a língua. Então eu acreditava que deveria me manter fiel à palavra. Existem outras, e estou ciente de todas as tentativas de re-situar ela de outra forma, num contexto da língua portuguesa, e assim por diante, no Brasil, por exemplo. Mas penso que nós teríamos que ultrapassar determinadas barreiras, cognitivas inclusive, conceituais e políticas e ideológicas e enfrentar a questão queer pela contribuição extraordinária que ela tem que dar sob o ponto de vista da sua amplitude semiológica. Eu penso que a Queermuseu obviamente tinha o papel de traduzir isso a partir de obras, imagens. Eu considero a Queermuseu uma exposição de imagens, mesmo com obras tridimensionais. Considero que a gente devia pensar a Queermuseu como um mundo das imagens. E eu creio que esse entendimento do mundo a partir de uma perspectiva queer, assim como por exemplo, a partir de outros sentidos que não sejam exclusivamente aquele do olhar, no caso do olfato, ou do tato e assim por diante. $\mathrm{O}$ tato é meio automático para nós porque somos não só obrigados a tocar nas coisas, mas muitas vezes proibidos de tocar nas coisas, como é o caso de objetos museológicos. A consciência do tato para nós é quase que inerente, enquanto que o olfato é perturbador. E esses lugares da perturbação são importantes porque, para mim eles estão dentro do território da desobediência civil. Que aliás, é uma coisa que sofreu uma distorção e se transformou num campo de batalha e de ataques, inclusive de setores da extrema direita e em direção aos setores mais progressistas da sociedade. A Hannah Arendt tem um texto de 1970, sobre desobediência civil, na revista The New Yorker, e ela fala que a desobediência civil é fundamental porque é o mecanismo contra-jurídico num certo sentido, e que permite a manifestação das diferenças sob o ponto de vista qualificado, se eu tivesse que resumir numa frase um artigo de 30 páginas. Então é muito importante essa perturbação. Veja bem que eu estou no universo da arte, ela ingressa nesse território e trazer isso para dentro de uma exposição é importante para mim. E qualquer manifestação queer, o que é muito ampla, um guarda-chuva que seja, o que é muito amplo, e que consegue ingressar em territórios da arte, da cultura e diversos outros setores, ela é muito instrumental para nós termos outras avenidas de pensamento e de intervenção política. Eu sou simpático à ideia de inserir o queer na sigla LGBT, ou seja, LGBTQ, porque 
as outras denominações são mais restritivas e o queer é mais amplo, ele consegue abarcar algumas coisas que as outras não conseguem. Isto está na literatura, não é também nenhuma novidade. Mas eu entendo que para muitas pessoas ela é um incômodo porque como sai muito do universo identitário e essencialista, parece que fica uma coisa meio despolitizada. Eu percebo isso na cabeça das pessoas, mas não acho assim. Eu acho que é o contrário, mas veja bem que não é consenso. É um pouco isso que a exposição objetivava.

Eu queria concluir com uma coisa, que é o seguinte (eu posso dizer uma frase que é muito categórica e eu vou fazer uma defesa dela, tenho feito e tenho vencido essa defesa): eu penso que a Queermuseu inaugura para a sociedade brasileira, de forma definitiva, um debate sobre gênero e sexualidade no Brasil. As pessoas poderiam dizer que isso já existia. Mas era restrito, no âmbito da academia, nas pautas da comunidade LGBT, no movimento feminista, evidentemente, mas não na escala extraordinária que a Queermuseu projeta, onde lá no interior alguém ordenhando as vacas está discutindo a exposição, nos aniversários, nas festas de família, casais se separaram por causa da exposição, outros se conheceram por causa da exposição. As pessoas ficaram um ano debatendo esse assunto. Por qualquer via que fosse, pelo bem ou pelo mal, elas estavam debatendo esse assunto. Então ela inaugura isso de uma maneira definitiva e, ao mesmo tempo faz isso a partir de um diálogo que se considerava até então impossível, que uma exposição de arte pudesse fazer isso. E derruba uma outra barreira que é a seguinte: exposições de arte são extremamente elitistas, destinadas a um grupo restrito de iniciados e elas não podem ser debatidas no espaço público, na arena pública. E a Queermuseu derruba essa barreira.

\section{A Queermuseu cumpriu seus objetivos?}

Sem dúvida! Eu acho que a grande contribuição que ela dá é justamente instituir esse debate e fazer esse debate através da arte. Ou seja, goste ou não goste de arte, as pessoas têm que passar por ele, não tem jeito. 